\title{
Project Governance in State-Owned Enterprises: The Case of Major Public Projects' Governance Arrangements and Quality Assurance Schemes
}

\author{
Anne Strand Alfredsen Larsen ${ }^{1,2, *(\mathbb{D}, \text { Gro Holst Volden }}{ }^{3}$ and Bjørn Andersen ${ }^{2}$ (i) \\ 1 Ålesund Hospital, Møre and Romsdal Hospital Trust, 6026 Ålesund, Norway \\ 2 Department of Mechanical and Industrial Engineering, Faculty of Engineering, Norwegian University of \\ Science and Technology, 7491 Trondheim, Norway; bjorn.andersen@ntnu.no \\ 3 Department of Civil and Environmental Engineering, Faculty of Engineering, Norwegian University of \\ Science and Technology, 7491 Trondheim, Norway; gro.holst.volden@ntnu.no \\ * Correspondence: anne.strand.alfredsen.larsen@helse-mr.no or annestra@stud.ntnu.no
}

Citation: Larsen, Anne Strand Alfredsen, Gro Holst Volden, and Bjørn Andersen. 2021. Project Governance in State-Owned Enterprises: The Case of Major Public Projects' Governance Arrangements and Quality Assurance Schemes. Administrative Sciences 11: 66. https://doi.org/10.3390/admsci 11030066

Received: 10 May 2021

Accepted: 30 June 2021

Published: 2 July 2021

Publisher's Note: MDPI stays neutral with regard to jurisdictional claims in published maps and institutional affiliations.

Copyright: (c) 2021 by the authors. Licensee MDPI, Basel, Switzerland. This article is an open access article distributed under the terms and conditions of the Creative Commons Attribution (CC BY) license (https:// creativecommons.org/licenses/by/ $4.0 /)$.

\begin{abstract}
Societal development is increasingly undertaken as major public projects in different sectors. Project governance is important for strategically successful outcomes; thus, a broad societal perspective should be kept throughout the governance process. State ownership exists in many forms, and major public projects' governance arrangements differ. Quality assurance is a recommended part of the arrangements, yet knowledge of them is limited. This study investigates relatively recent governance arrangements in state-owned enterprises in Norway, emphasizing their content and organization of quality assurance. The arrangements are compared with the more established "State Project Model", a governance arrangement set up by the Ministry of Finance in 2000, including major public projects with budgets exceeding USD 110 million. Through case studies, comprising documents and interviews, and using the State Project Model as a reference frame, differences in the studied arrangements' comprehensiveness were found. Finding the appropriate level of governance is challenging, yet potential for mutual learning and improvement across different arrangements is revealed. For state-owned enterprises with sectoral policy objectives, the government should ensure that political control is not undermined. This study provides recommendations for further improvement of governance arrangements and adds to the general understanding of state-owned enterprises and major public projects' front-end phase.
\end{abstract}

Keywords: project governance; state-owned enterprises; public projects; quality assurance

\section{Introduction}

Worldwide, there is an increase in societal development undertaken as major public projects, comprising among others public construction projects, transport infrastructure, and major ICT projects. Further, the projects have become constantly larger in scope and monetary terms (Flyvbjerg 2014). However, public projects have gained a bad reputation due to cost overruns and time delays, "over budget, over time, over and over again" (Flyvbjerg 2014, p. 6; 2017), and poor value for money (Volden 2019a). Although privatesector projects do not face the multifaceted challenges experienced in public projects, mainly resulting from political aspects, some of the discovered challenges also exist for private-sector projects (Volden and Samset 2017b).

Governance regimes for major projects are means for giving direction and help to improve processes and systems affiliated with such projects to ensure successful investments (Locatelli et al. 2014; Samset et al. 2006). A project governance regime comprises processes, systems and regulations that need to be in place for the project owner to ensure that the best project is chosen and implemented efficiently (Volden and Andersen 2018). Different approaches to governance due to organizational or sector characteristics, such 
as shareholder orientation or orientation towards societal responsibilities, are needed and have been identified (Campbell et al. 2010; Müller 2014).

The private sector often expresses objectives connected to financial profitability and is guided by market signals, aiming to maximize return on investments (Campbell et al. 2010; Klakegg et al. 2016). Impacts are measured in monetary terms such as return on investment and incentives are connected to productivity and effectiveness, and organizations face less red tape (Campbell et al. 2010).

Public projects are complex due to, for example, multiple objectives, multiple stakeholders and difficulties in measuring success (Klakegg and Volden 2017). Political influence is prominent in public settings (Ongaro and Ferlie 2019), and must be considered as part of the projects' strategical efforts. Furthermore, the public sector demonstrates internal challenges due to a lack of skills and insufficient coordination between levels and among different actors (Volden and Andersen 2018). The inherent complexity represents a differentiation from the private sector, thus placing specific emphasis on governance (Crawford and Helm 2009). Furthermore, the complexity makes governance regimes or systems important for making things more predictable, which in turn positively affects the decision-making processes, thus safeguarding the interests of the project owner, namely the wider society and all taxpayers (Volden and Andersen 2018).

Previous research has looked at governance regimes for public projects and the effects that can be obtained, but also their weaknesses and limits. For example, Volden and Samset (2017b) present and discuss governance regimes in six countries, and find that the studied different regimes shared many characteristics and were mainly in compliance with recommendations from literature. For example, it was found that all schemes required independent quality assurance (QA) of decision documents, which is also highlighted by Narayanan and DeFillippi (2012), and by Haanæs et al. (2006).

In Norway, the Ministry of Finance established the State Project Model (SPM) in the year 2000. The SPM, also termed the "quality assurance scheme", aims at countering the problems and challenges experienced in major public projects that potentially lead to unfortunate project outcomes. In the last 20 years, trailing research has been performed on the SPM, showing that the preliminary effects of using this type of governance arrangement are positive: cost control is achieved on the portfolio level, there is more focus on problems than solutions, and the government is involved earlier (Volden and Samset 2017a). However, the regime is perceived as both time and resource demanding, and some researchers refer to the scheme as characterized by red tape (ibid.).

The SPM in many ways reflects public reforms: it partly rests on New Public Management (NPM) thinking (by requiring truly external QA in projects' front-end phase, using external experts), but also keeps a strong political aspect in that societal needs and goals are the basis for the experts' assessments (Christensen 2009). Public governance regimes should find the porper balance between efficiency and political control, which has proven a difficult task (ibid.). The SPM aims at managing this balance, but results show that governance tasks are extensively delegated to subordinate agencies, including strategical tasks that should be handled at the ministry level, thus risking a too narrow and internal focus (Volden and Andersen 2018).

As a result of different waves of public reforms, the public sector in many countries has been restructured through devolutionary elements in the form of new or reorganized state-owned enterprises (SOEs) (Christensen and Lægreid 2003). SOEs were established to encourage more rational and efficient decisions due to growing public deficits and a belief in private sector superiority over the public sector in terms of efficiency, and the need to reorganize in order to facilitate growing cooperation between the private and public sectors as a result of structural transformations (Grossi et al. 2015; Rentsch and Finger 2015). Today, the presence of SOEs is considerable worldwide, as described by several authors, e.g., Ciolomic and Beleiu (2020), Nasir (2017), and Vagliasindi (2008), concentrated in sectors regarded as either strategical or important for the broader economy (Bernier and Reeves 2018; OECD 2014). SOEs are partially or wholly owned by the state, and consequently take 
many forms (OECD 2018). Generally, they are organized as independent entities, subject to performance targets, and at arm's length from politics. The SOE represents a hybrid organization in which both commercial and societal objectives should be considered, thus differing from both the private sector and ordinary public agencies (Nasir 2017).

Major projects undertaken in Norwegian SOEs are not included in the SPM, hence there is limited knowledge of how project governance is performed in this setting. Furthermore, there is limited knowledge regarding the QA element in governance arrangements in general, and in SOEs in particular, which serves as the motivation for this study.

This study aims at learning more about the SOEs' governance arrangements by exploring different arrangements' scope, actors and content, which also echoes the call for more knowledge of SOEs in general (e.g., Bernier and Reeves 2018; Grossi et al. 2015). The present study focuses on five Norwegian SOEs, comparing them with the more established Norwegian SPM. Knowledge of the latter model, following several years of trailing research, makes it a beneficial starting point for comparison, also considering earlier findings suggesting that the SPM corresponds to recommendations found in extant governance literature (Volden and Samset 2017b; Volden and Andersen 2018). Studying any similarities and differences between the SOEs' arrangements and the SPM is a suitable point of departure for improvement and mutual learning between the arrangements. Gaining more insights into the different arrangements will create a basis for knowledge sharing, which is shown to have a positive impact on performance of both public and private organizations (Amayah 2013; Nesheim and Hunskaar 2015). In a project environment, knowledge sharing is proven to be beneficial in many ways on the individual level, and for some projects, it is shown that knowledge sharing improves project performance (Ali et al. 2018; Hussein 2020; Imam and Zaheer 2021).

Drawing on the established knowledge of public governance arrangements, some preliminary expectations as to potential differences between the arrangements and the $\mathrm{SOEs}^{\prime}$ arrangements existed. Due to the SOEs' organizational independence and intentions of improved efficiency, it could be expected that the governance arrangements in these enterprises would focus more heavily on efficiency and in different aspects: efficient projects, but also efficient implementation of QA and other governance activities. The organizational independence also makes it interesting to look into how political control is ensured in SOEs' projects, and how external expertise is utilized.

Hence, to explore governance arrangements in SOEs, this study aimed at gaining more insights into the following topics:

- A description of different SOEs' arrangements' and their purpose, especially on how external QA is organized and performed;

- Actors and roles, including their political aspect;

- The arrangements' scope, and cost and time efficiency.

Five Norwegian SOEs that used to be government agencies but were reorganized to SOEs in the period 1992-2017, and thus became responsible for establishing their own governance arrangements for major projects were studied. The SOEs were compared with the SPM. All five SOEs have sectoral policy objectives and are owned by the line ministry responsible for the sectoral policy in the relevant area. The SOEs' investment projects comprise airports, specialist health care, the national electricity grid, highways, and railroads.

This paper starts by reviewing the theoretical foundation for the current study, comprising three strains of literature: governance of projects, projects in the private and public sectors and finally the state-owned enterprises. The research design, data collection and data analysis are then presented, followed by study findings from document reviews and interviews, and subsequent discussion including the researchers' assessments. Finally, some concluding remarks are presented together with this study's implications. 


\section{Theoretical Background and Literature Review}

This study is underpinned by three theoretical topics—governance of projects, projects in the private and public sectors, and state-owned enterprises. It is argued that the intersection of these topics reveals a research gap connected to limited knowledge of the performance of project governance in SOEs, the poor understanding of the QA element in governance arrangements in general and the general call for more insight into the SOEs, as mentioned in the Introduction section.

In this section, this study first looks into the rather recent topic of project governance. Thereafter, this study looks at private and public organizations' inherent differences that presumably affect the different sectors' projects and their governance regimes. This study then delve into the SOEs, as the main organizational object of this study, which are hybrid organizations comprising elements both from private and public organizations.

\subsection{Governance of Projects}

In general, governance refers to the administrative and process-oriented elements of governing, whether undertaken by a government, market or network, whether over a family, tribe, formal or informal organization, or territory, and whether through laws, norms, power, or language (Bevir 2013). Governance can be defined on many levels, is found both in public and private sectors, comprises many fields (e.g., corporate, public, administrative), and is a relative concept, meaning that "one size does not fit all" (Klakegg et al. 2008). Further, governance should cover all organizational levels.

Project governance is a rather recent research topic in the project management community. Initial theoretical contributions are mainly found after the year 2000, with a much-cited textbook by Müller published in 2009 (Müller 2009). Klakegg et al. (2008) refer to a paper by Miller and Hobbs (2005, p. 47), where it says that: "Project governance has only recently become an issue of importance in the project management community and literature. Over the last ten years there has been more interest in the governance of projects in general and the governance of large complex public projects in particular". Project governance can further be seen as a subset of corporate governance (Müller 2009), and concerns areas related to project activities that should ensure the alignment of the organization's project portfolio to its objectives (Klakegg et al. 2008).

Project governance literature appears fragmented (Ahola et al. 2014; Volden and Andersen 2018). Among the different streams of literature dealing with project governance, a distinction is made between governance of projects and governance through projects (Williams et al. 2010). This corresponds to levels of project success, as suggested by Samset (2010), which comprise the operational project perspectives (i.e., efficiency and cost compliance) versus the tactical and strategical perspectives (i.e., the extent to which the conceptual choice provides relevant and sustainable outcomes for society). The latter implies "doing the right project", wherein, among other issues, dealing with complex decisions plays a major part (Williams and Samset 2010). Other distinctions are pointed at by Ahola et al. (2014), where project governance is found to either be external to any specific project (literature within project management) or internal to a specific project (literature also includes transaction cost economics).

Project governance refers to the processes, systems and regulations that the financing party must have in place to ensure that projects are successful (Samset and Volden 2016). Typically, these include a regulatory framework to ensure adequate quality at entry, compliance with agreed objectives, management and resolution of issues that may arise during the project, and standards for quality review of key appraisal documents (Samset and Volden 2016). A recent paper by Khan et al. (2019) summarizes work on project governance and which elements should be included in governance arrangements. Haanæs et al. (2006), who reviewed different models for decision making in major public projects based on best practice in Norway and other countries, also contribute to the topic by suggesting the following minimum requirements:

- Clearly defined project phases, 
- Clearly defined decision points between the phases,

- Quality-assured basis for the decisions,

- Simplicity, and

- A certain standardization and common terminology.

The different publications show similarities in their content requirements for governance schemes. The need to include QA of the decision basis is pointed out by Haanæs et al. (2006) and by Narayanan and DeFillippi (2012). Experiences relating to the Norwegian SPM show that QA is beneficial for project performance. Studies show both improvement in cost management $(80 \%$ of projects are completed within the cost frame, and on the portfolio level, the State is now in good control) (Samset and Volden 2013a), and the benefits of the systematic appraisal of conceptual solutions. The early appraisals force planners to view the potential investment in a holistic societal perspective rather than drawing specific technical conclusions directly, and it is shown that quality assurers' recommendations on conceptual choices are largely taken into account by decision makers (Samset and Volden 2013a).

The importance of early appraisals makes certain project phases more critical and in need of governance arrangements than others. A number of authors have highlighted the crucial role of the front-end phase (Morris 2013; Samset and Volden 2016; Williams et al. 2019). This is the stage from when the idea is conceived until a final implementation decision is made, and during which it is still possible to make changes or to terminate the project, at an affordable cost.

Many of the factors that later create problems in the construction phase, leading to cost overruns and other problems, are typically present early in the project definition stage (Morris 2009). Several authors (Klakegg and Haavaldsen 2011; Samset and Christensen 2017; Williams and Samset 2010) note that the choice of concept has the largest impact on strategical project success and is thus highly critical. Strategical project success refers to the achievement of successful project outcomes over a project's life cycle (Jugdev and Müller 2005) and connects to long-term value creation and sustainability of the actual project result (Williams and Samset 2010). Project management success, on the other hand, refers to the delivery of an expected project output often connected to the iron-triangle of time, cost and quality (Williams and Samset 2010). Sufficient exploration of the opportunity space by developing and evaluating alternative concepts serves to increase the odds of finding the best concept, but findings indicate that unfortunately this is not always the case (Samset et al. 2014). Furthermore, Müller (2009) emphasizes that the selection and prioritization of projects are key issues in a project governance scheme, and are closely related to the organization's portfolio management. Further, decision making is viewed as the link connecting governance and improved project performance (Turner 2020a, 2020b). The front-end's inherent complexity and uncertainty make decision-making challenging, thus the front-end becomes reliant on knowledge sharing (Serugga et al. 2020), which is also recommended to overcome uncertainty (Stock et al. 2021). To further help overcome front-end challenges, the value of judgmental information is put forward, and the ability for groups to provide better probability assessments by working together and sharing knowledge and experiences, rather than the individual working alone (Imam and Zaheer 2021; Samset 2009). Facilitating knowledge sharing through suitable arenas to provide for improved performance is connected to the management's role (Hussein 2020; Söderlund 2002), thus part of the governance regime.

Most of the project governance literature has its origins in the private sector, but the findings and recommendations may also be relevant to the public sector. Some studies focus on the governance of state-funded projects at the country level in relation to political processes and policy forming (Klakegg et al. 2016; Volden and Samset 2017a; Williams et al. 2010). Their perspective is on overarching institutional arrangements established by central governments to ensure that projects succeed across different public organizations. In general, Frey (2005) claims that possibilities exist for the private sector and corporate governance to learn from public-sector governance by constraining managerial power 
through the division of power, rules and institutionalized competition, widening the extrinsic motivation to include more than monetary incentives, and by using goal-oriented intrinsic motivation, as opposed to extrinsic incentives.

The complexity surrounding major public projects affects the decision-making processes by creating uncertainty and unpredictability (Daniel and Daniel 2018) and is further complicated by analytical and political deficiencies (Samset and Volden 2016). Thus, the final decisions often become the result of policy and preferences (Samset et al. 2014), which highlights the well-known challenge of balancing concept elaboration and political decision making (Klakegg et al. 2016). The complexity may also pose a challenge for QA instruments, and thus there is need for continuous improvement in order to remain effective (Klakegg et al. 2016; Williams et al. 2010). This further emphasizes the need for governance regimes, with proper systems, processes and tools, able to meet these challenges (Khan et al. 2019; Turner et al. 2013; Volden and Andersen 2018). Governance frameworks serve as a guide to navigation through the complex landscape that encompasses public projects, thereby strengthening their odds of success by creating predictability and a sufficient analytical basis for decision making, and thus securing political control. However, there is no guarantee of improved decision making through such systems (Christensen 2011).

\subsection{Private versus Public-Sector Projects}

Both in the private and public sectors, projects are the means for change and development. Projects are instruments for implementing both strategies and policies. However, there are some fundamental differences between the two sectors and the differences affect how project governance is performed (Crawford and Helm 2009). These differences are becoming increasingly blurred due to a growing similarity in roles and context, and due to public reforms, privatization and corporatization (Campbell et al. 2010). Project governance should ensure that a project contributes as expected by defining standards with which the project should comply and further monitor this compliance, which makes the project's organizational structure, its shaping and institutional framework, and its ability to self-regulate all necessary elements in project governance (Too et al. 2017).

When looking at projects as important tools for strategical decision making, differences between the private and public sectors can be described, in line with Nutt (2006), in terms of environmental, transactional and process factors. Environmental (external) factors comprise, among other things, the considerations of a multitude of stakeholders, collaboration instead of competition, limitations in autonomy and flexibility aiming for consensus, and the need to balance political demands and user needs in a public context. The political influence is more prominent in the public sector than in the private sector, and modifies strategical management (Ongaro and Ferlie 2019). The transactional factors point at public scrutiny and the involvement of several actors in decision-making processes in the public setting, whereas private organizations mainly serve shareholders' aims for financial benefits. Furthermore, organizational processes are often seen as more comprehensive in a public organization, due to multiple and changing goals, and conflicts resulting from multiple stakeholders with different views and diffused power, which affects decisions. Hence, the complexity inherent in public organizations will affect governance regimes making them more comprehensive and probably less effective than those in private organizations, where the overall aim is to maximize return on investment (Campbell et al. 2010).

Public projects should also provide value for money, defined by social benefit-cost analysis (Volden 2019b). Additionally, the projects need to cope within the broad societal context, and should be successful at an operational, tactical and strategical level (e.g., Samset and Volden 2016; Volden and Andersen 2018; Williams and Samset 2010), which also indicates that the traditional ideal technocratic planning model is unrealistic (Christensen 2009). 


\subsection{State-Owned Enterprises (SOEs)}

SOEs are partially or wholly owned by the state. Several organizations provide definitions of SOEs. However, a shared definition is absent (McLaughlin 2019). This research, with its primary focus on project governance, uses the definition provided by OECD since governance connected to SOEs is studied and reported by the OECD (McLaughlin 2019; OECD 2018), and since Norway is a member of the OECD. SOEs were established to encourage more rational and efficient decisions, due to growing public deficits and a belief in private sector superiority over the public sector in terms of efficiency and the need to reorganize in order to facilitate growing cooperation between the private and public sectors as a result of structural transformations (Grossi et al. 2015; Rentsch and Finger 2015). Additional reasons for establishing such enterprises are change of markets, desire to improve effectiveness and efficiency and to provide better services, the need for a clearer division of responsibility between owner (ministry) and management, and political considerations involving the transference of responsibility and decision making to enterprises in order to unburden political responsibilities (Statskonsult 1998). Moreover, SOEs take many forms (OECD 2018), and are considered important means for sectors that are essential and strategically important to government (Bernier and Reeves 2018). In a study of 34 countries $^{\prime}$ SOEs, it was found that 6 million people were employed in the enterprises, although the variations among countries were large, and the largest SOE sectors seemed to be found in the countries with the largest economies (OECD 2014).

The organization of the SOEs may be considered a gray area between state ownership and autonomy, as illustrated in Figure 1.

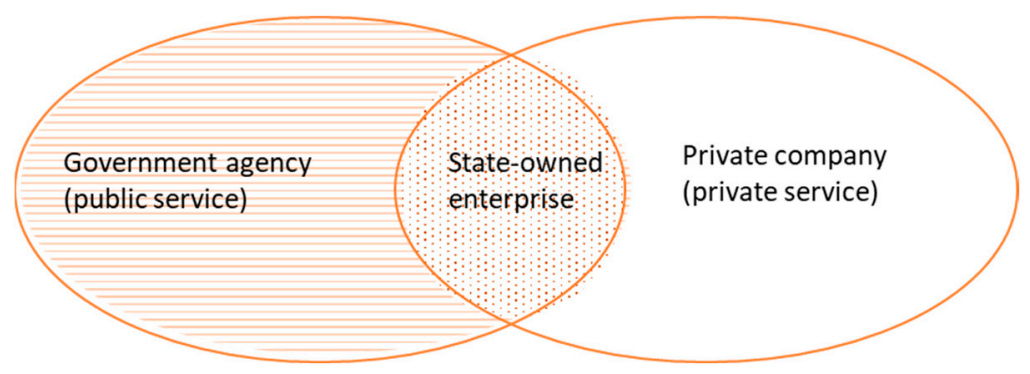

Figure 1. The SOE at a public-to-private organizational scale.

Although the SOEs manage important public interests, they largely run their own investments and decision processes happen at political arm's length. Their owners (i.e., ministries) define their goals, which may or may not reflect broad, societal objectives, and may require that decisions with political aspects are elevated to the political level. Thus, the SOEs' governance arrangements represent trade-offs between the decentralization and centralization of decision making, which should be handled with caution. Such distancing may affect how agency officials pay attention to political principals (Overman 2016), also considering that too much identification with an organizational subunit might lead to decisions that benefit the subunit rather than the larger organization (Simon 1944).

How decision-making authority should be delegated may follow several principles or instruments. The level of uncertainty and level of conflict are seemingly important issues for delegating authority (Huber and Shipan 2013). It is also argued that self-autonomy is less both when the enterprises are large and dependent on subsidies and when societal objectives lead to political visibility (Sørensen 2010). Reduced self-autonomy might compromise efficiency due to the enterprise having less ability to adapt decisions for the environment, while too much self-autonomy might lead the enterprise to make decisions that are not in line with the state's objectives (Sørensen 2010). This in turn elucidates some of the factors constituting the ambiguity found in the relationship between the state and the SOEs, where the SOE strives to balance its independency with non-market strategies and the need for protection and security (Rentsch and Finger 2015). 
The SOEs are in charge of considerable public values, which makes demands on their effectiveness and efficiency, sustainability, and transparency (Grossi et al. 2015). This affects the governance frameworks encompassing the major projects undertaken in these enterprises, in line with the three dimensions of efficiency, legitimacy and accountability, discussed by Brunet and Aubry (2016), who argue that performance should be considered from other perspectives than merely the efficiency perspective.

\section{Methodology}

The following subsections present the research design, data collection, data analysis and limitations of this study. The methodological steps of the research are summarized and presented in Figure 2, at the end of this section.

\subsection{Research Design and Data Collection}

The research for this study was designed as a qualitative case study using an exploratory and descriptive approach (Saunders et al. 2019; Yin 2014). Each SOE's project governance scheme was treated as a case, using the SPM as a frame of reference. The purpose of this study was to seek deeper insights into the governance arrangements in the SOEs, which justified the use of an exploratory case study approach (Saunders et al. 2019; Yin 2014).

The selected SOEs are "category 3 companies", which are non-competing companies for which the Norwegian State has sectoral policy objectives. All studied SOEs are wholly owned by the state (category 3 also comprises companies with different levels of state ownership), and all companies were reorganized as SOEs by government agencies in the period 1992-2017. Investment projects undertaken in the selected SOEs can all be characterized as major projects that would normally be subject to the SPM.

This study's mandate was thoroughly prepared by the researchers and further extensively discussed in a reference group that was established prior to data collection and comprised representatives from all the involved ministries. The reference group arranged for contacts in the SOEs when needed and was given the opportunity to give comments leading to the final study report.

Empirical data were sourced from document reviews and interviews. Document studies are particularly suitable for case studies aiming for thorough insights into a topic, and are efficient and cost-effective means for research (Bowen 2009). Documents from each governance scheme were studied, including the SOEs' project governance models with inherent guidelines, reports from the quality assurers, and minutes from board meetings or other decisive entities in which reports are used as part of the decision basis. The documents were accessed by contacting SOEs directly, using information provided by the reference group when needed.

Interviews are suitable as a data collection method aiming for deeper insights into a specific topic (Kvale and Brinkmann 2015; Saunders et al. 2019). We interviewed 45 respondents comprising representatives from line ministries and SOEs, and quality assurers with knowledge of several arrangements (Table 1). The respondents were sampled using a purposive sampling strategy (Marshall 1996; Saunders et al. 2019), for which the external quality assurers should have been familiar with at least two of the governance arrangements studied as an inclusion criteria. Generally, the document studies were conducted prior to interviews. Data were collected between March and November 2019. 
Table 1. Overview of the respondents.

\begin{tabular}{|c|c|c|c|}
\hline & & Sector & No. of Respondents \\
\hline Ministries & $\begin{array}{l}\text { Transport and communications } \\
\text { Petroleum and energy } \\
\text { Health and care services } \\
\text { Finance }\end{array}$ & $\begin{array}{l}\text { Road, rail, air } \\
\text { Electricity grid } \\
\text { Hospitals } \\
\text { SPM }\end{array}$ & 11 \\
\hline SOEs & $\begin{array}{l}\text { Regional health authorities } \\
\text { Norwegian Hospital Construction Agency } \\
\text { Avinor } \\
\text { Nye Veier } \\
\text { Bane NOR } \\
\text { Statnett }\end{array}$ & $\begin{array}{l}\text { Hospitals } \\
\text { Hospitals } \\
\text { Air } \\
\text { Road } \\
\text { Rail } \\
\text { Electricity grid }\end{array}$ & 18 \\
\hline Regulative authorities & $\begin{array}{l}\text { Norwegian Water Resources and Energy Directorate } \\
\text { Railway Directorate }\end{array}$ & $\begin{array}{l}\text { Electricity grid } \\
\text { Rail }\end{array}$ & 4 \\
\hline Others & Researchers & & 2 \\
\hline Quality assurers & $\begin{array}{l}\text { Holte Consulting } \\
\text { Metier OEC } \\
\text { Atkins Norway } \\
\text { WSP Norway } \\
\text { DNV GL } \\
\text { Vista Analyse }\end{array}$ & & 10 \\
\hline
\end{tabular}

Our contacts in the SOEs also suggested potential interviewees. In addition, quality assurers with experience of several of the QA arrangements were invited to be interviewed, in order to enable comparisons and provide for inputs on strengths and weaknesses in the different arrangements. The interviews were semi-structured, which enabled the use of open-ended questions and allowed for flexibility to change the order of the questions and adaptation to the situation (Saunders et al. 2019; Tjora 2012). All respondents were informed prior to the interviews, enabling them to prepare by gathering documentation and reflecting on earlier events, which has strengthened this study's validity and reliability (Saunders et al. 2019). An interview guide was used as a point of departure based on topics from this study's mandate, but the respondents could also speak freely, thus enabling them to delve deeply into topics in which they had thorough insights. Semi-structured interviews also provided opportunities for the respondents to discuss/draw attention to topics that were not directly asked about, thereby permitting digressions that enabled the exploration of different angles of the main topic not thought of beforehand (Tjora 2012). To clarify any uncertainties resulting from the document studies and to verify our own understanding, the respondents were also asked directly about the uncertainties in the interviews. Each interview lasted $1-2 \mathrm{~h}$ and was conducted by two or more researchers, one of whom made detailed notes. The findings from the document studies and interviews were used to make comprehensive case descriptions. The respondents were offered the chance to read the interview notes, but the majority were satisfied with just reading and commenting on the case descriptions.

Individual projects were not studied, only project governance arrangements set up by the line ministry and/or SOEs themselves. It should be noted that some schemes are quite recent, thus experiences so far are limited. Therefore, only the characteristics of the arrangements, not the effects of the arrangements, are discussed. The steps of the research are illustrated in Figure 2. 


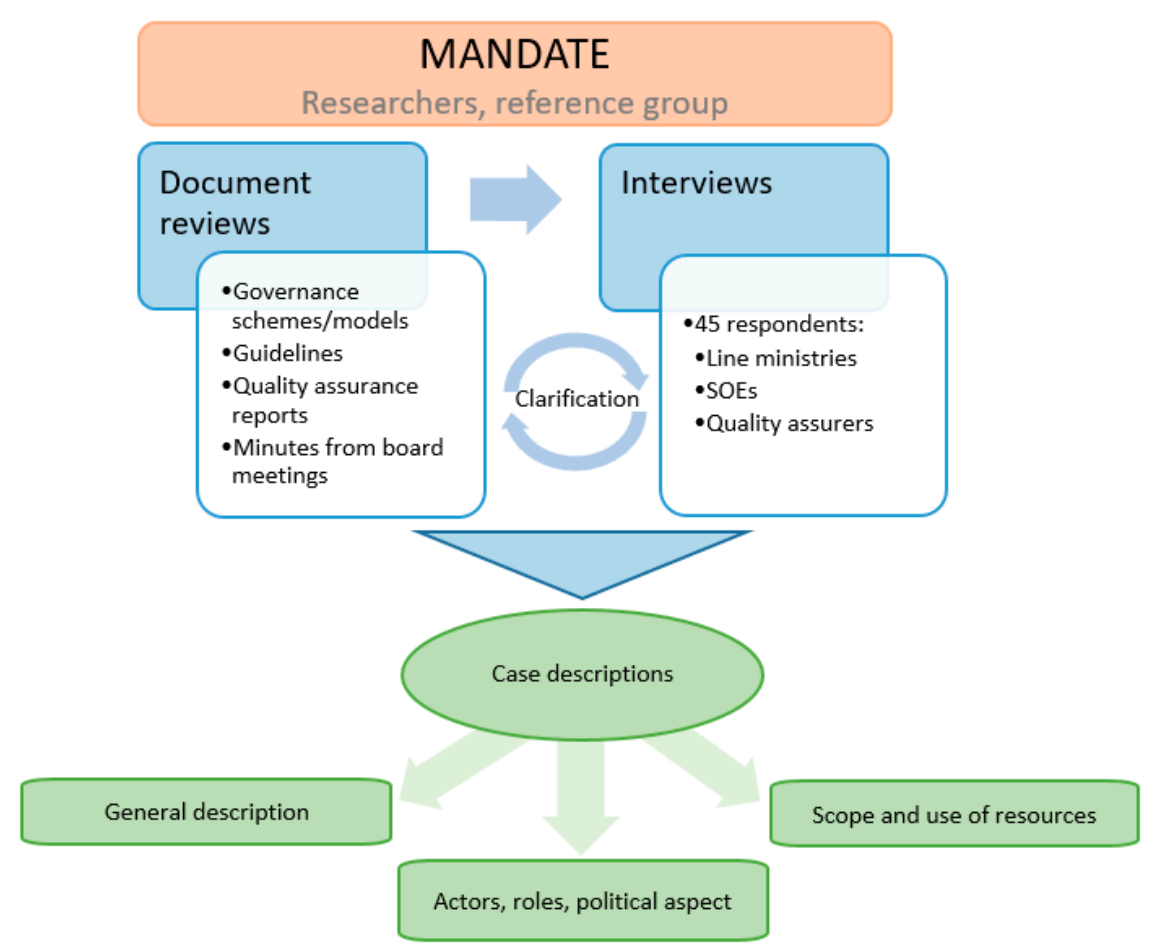

Figure 2. Research steps.

\subsection{Data Analysis}

The collected data were analyzed following two paths. The governance schemes' formalities were compared by using tables, looking at organizational issues and timelines and other aspects characteristic of the respective arrangements. This revealed the schemes' similarities and actual differences related to the schemes' content, performance and process.

The interviews were analyzed by coding the respondents' different statements, and further by clustering similar statements. The findings from the interviews partly helped to clarify or supplement the findings from the document study, but topics emerged that were not found in the document study and enabled us to gain deeper insight into aforementioned findings and thus the QA process.

Using data from multiple sources and combining methodologies are means for triangulation, which is important for validation and hence strengthens a study's trustworthiness (Saunders et al. 2019). Triangulation further enables a broad perspective and adds depth to the research (Ibid.). Moreover, studying several cases enables researchers to note similarities or convergence of information that could strengthen their study's credibility (Bowen 2009), as was experienced in our research.

\subsection{Limitations}

This study is limited to one country, and some of the arrangements are quite recent, which makes it too early to assess their effects. Therefore, the findings should be interpreted with caution, and they are not generalizable beyond the studied context.

Since the interviews were not audio recorded, there might have been an increased risk of introducing bias from the interviewer, as well as potential lack of accuracy. However, two researchers were always present in the interviews, during which one was responsible for taking notes, and all interviewees were given the opportunity to read the interview notes afterwards to mitigate the aforementioned limitations. Some of the interviewees, especially the quality assurers, provided personal interpretations of the studied arrangements. These interpretations were often in accordance with the researchers' interpretations, which occasionally made it difficult to separate explicitly the interviewees' interpretations from the researchers' interpretations. An effort is made to state the researchers' interpretations and assessments clearly by having separate subsections in the "Results and discussion" section. 


\section{Results and Discussion}

This section provides the results and discussion of this study findings. First, the studied cases are described, then the three main topics and subtopics that emerged from the analyses are described and discussed.

\subsection{Case Descriptions}

The studied cases comprise the SPM and five SOEs with sectoral policy objectives (category 3 companies), which are explained in the following sections.

\subsubsection{The State Project Model (SPM)}

Every year, the Norwegian State invests millions of USD in major public projects from different sectors. To prevent future problems connected to cost overruns, delays and unrealized benefits, the Norwegian Ministry of Finance (hereafter abbreviated as MoF) established the SPM for major public investments in the year 2000 and further expanded it in 2005 to include the choice of concept. The model's purpose is to ensure quality and consistency of analysis and decisions in the front-end phase of projects, and it comprises a stage-gate model with two decision points (QA1 and QA2) (Figure 3).

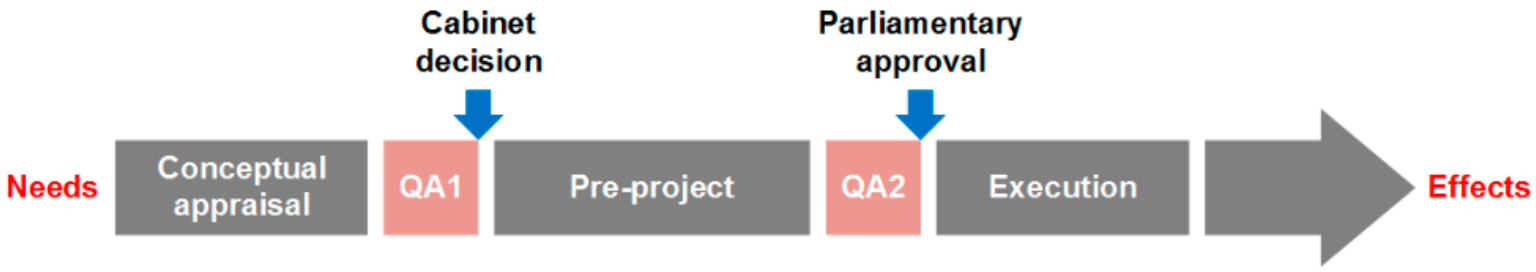

Figure 3. The State Project Model.

The regime has undergone some minor changes over the years, but the decision points have remained. QA1 concerns the choice of concept, where the purpose is to give the central political level real control over investment decisions. QA2 concerns the management base and cost estimates, where the purpose is to ensure budget realism and to obtain a more efficient use of resources.

Today, major public projects performed by ministries or governmental enterprises that are expected to exceed an investment cost of USD 110 million are subject to external QA through the State Project Model, with the intention to ensure quality-at-entry prior to the final funding decision (Ministry of Finance 2019). The MoF has entered into framework agreements with private consultants who perform the external QA, but the final decision is a political one. The QA is an assessment of the projects' decision documents comprising certain contents defined by the MoF, and independent analyses performed by the private consultants.

The SPM shows encouraging results. According to Volden and Samset (2017a), control over cost is achieved, and alignment with the government's strategical and political goals is ensured. The introduction of QA1 has provided a more systematic approach to an early identification of project ideas, making planners take a broader societal perspective instead of presenting technical solutions directly, thus strengthening the odds of including the most efficient alternative in the analyses. Spin-off effects are seen also in other sectors and administrative levels (municipalities), where similar arrangements inspired by the SPM are voluntarily introduced.

Although preliminary results are positive, the SPM has been criticized for being too rigid and using large amounts of time and resources (Samset and Volden 2013b). The SPM is also said to allow for too much political involvement, and politicians do not always follow recommendations from rational analyses (Volden and Samset 2017a; Volden 2019b).

Norwegian SOEs' major projects are not covered by the SPM. However, line ministries may impose governance arrangements on SOEs' projects as owner and/or regulator. 
Beyond that, SOEs are responsible for their own investments, including their own QA schemes.

\subsubsection{The SOEs}

Public ownership is prominent in Norway, and the Norwegian State has considerable interests in traditional business activities, public infrastructure and traditional public sectors (Sørensen and Dalen 2001). Over the last 20-30 years, several Norwegian government agencies have been reorganized as SOEs with sectoral policy objectives, resulting from a number of large public reforms. In Norway, SOEs account for almost $10 \%$ of national employment, which is considerably higher than in other countries, where the share is below 5\% (OECD 2014). The wide-ranging state ownership found in Norway is claimed to be the result of pragmatic choices in a number of individual cases rather than the result of a long-term plan (Norwegian Ministry of Trade Industry and Fisheries 2019b). State ownership in Norway was further professionalized from the late 1990s, and the introduced state ownership practices/frameworks have been pursued despite changes of governments (Norwegian Ministry of Trade Industry and Fisheries 2019a).

The organization of state responsibilities in enterprises in Norway is further explained as a way of providing the enterprise with a higher degree of strategical, operational and professional independence than would be possible in government agencies. SOEs, as independent legal entities, are competent and responsible decision makers, whereas in the case of government agencies, the decisions are made on behalf of the state and authorized by the cabinet minister (Norwegian Ministry of Trade Industry and Fisheries 2019b). Compared with government agencies, the enterprise organization is more efficient when governmental tasks require specialized expertise and adaption to heterogeneous and changing environments, and when it is possible to govern by subsequent result assessments (Sørensen 2010). However, organizing state responsibilities in enterprises leads to a greater distance between the enterprise and the ministries (Norwegian Ministry of Trade Industry and Fisheries 2019b).

For the State to exploit the enterprises' inherent expertise and competence, the SOEs experience a strong degree of autonomy (Sørensen 2010). By assessing major public projects through the SPM, political governance is ensured by the State/government. However, the SOEs projects are not subject to this regime. The SOEs administer their own governance arrangements and thus have a far more independent role towards the State/government. This might constitute a potential risk for the SOEs to compromise the broad societal perspective that should be present for assessing their projects in order to achieve strategical success.

Norwegian SOEs are sorted into three categories based on the State's goals as owner and whether the State has a rationale for its ownership. The categories differ, dependent on the State's objectives, where categories 1 and 2 have mostly commercial objectives aiming for the highest possible returns over time and the companies are set in a competitive environment, whereas category 3 companies' objectives are to attain public policy goals as efficiently as possible and do not primarily operate in competition with other companies (Norwegian Ministry of Trade Industry and Fisheries 2019a). The line ministries responsible for the sectoral policy in the relevant area own the category 3 companies. The category 1 companies are companies with commercial objectives, and category 2 companies are those with commercial objectives and other specifically defined objectives, and all are owned by the Ministry of Trade, Industry and Fisheries.

The five studied SOEs are presented in Table 2. All five enterprises used to be government agencies, but were reorganized as SOEs in the period 1992-2017. Some are funded by user fees (revenues regulated by the authorities), others by the national budget (in compensation for public service obligations), or in the case of Avinor by extensive commercial activities at the airport (e.g., duty-free sales, car parking, hotels). Some of the studied enterprises generate profits for the government (e.g., Avinor, Statnett); the others are only required to be financially "in balance". 
Table 2. Overview of the studied SOEs.

\begin{tabular}{|c|c|c|}
\hline SOE & Responsibility & Objective of State Ownership \\
\hline Avinor & $\begin{array}{l}\text { Aviation company with aviation } \\
\text { operations business encompassing } 44 \\
\text { airports in Norway, as well as air traffic } \\
\text { control towers, control centers and other } \\
\text { technical infrastructure for safe air } \\
\text { navigation; the company also performs a } \\
\text { number of socially mandated tasks }\end{array}$ & $\begin{array}{l}\text { To own, operate and develop a nationwide } \\
\text { network of airports for the civilian sector and } \\
\text { provide joint air navigation services for the } \\
\text { civilian and military sectors }\end{array}$ \\
\hline Bane NOR & $\begin{array}{l}\text { Responsible for the planning, } \\
\text { development, management, operation, } \\
\text { and maintenance of the national railroad } \\
\text { network, traffic management and the } \\
\text { management of railroad property }\end{array}$ & $\begin{array}{l}\text { To ensure a cost-effective and } \\
\text { customer-oriented infrastructure manager for } \\
\text { the railroads and the development of good } \\
\text { transport hubs }\end{array}$ \\
\hline Nye Veier & $\begin{array}{l}\text { Undertakes the planning, construction, } \\
\text { operation, and maintenance of sections of } \\
\text { national highways covered by the } \\
\text { company's portfolio }\end{array}$ & $\begin{array}{l}\text { To achieve more cohesive and cost-efficient } \\
\text { development of safe national highways and } \\
\text { create added value compared with a } \\
\text { traditional approach to road construction }\end{array}$ \\
\hline Statnett & $\begin{array}{l}\text { Transmission system operator in the } \\
\text { Norwegian power system and is } \\
\text { responsible for the socioeconomically } \\
\text { rational operation and development of } \\
\text { the central power transmission grid }\end{array}$ & $\begin{array}{l}\text { To contribute to the socioeconomically } \\
\text { rational operation and development of the } \\
\text { central transmission grid }\end{array}$ \\
\hline Regional health authorities (4) & $\begin{array}{l}\text { Responsible for specialized health care } \\
\text { services in the country }\end{array}$ & $\begin{array}{l}\text { To guarantee specialized health services for } \\
\text { the four regions' populations by offering } \\
\text { high-quality and equitable specialized health } \\
\text { services to all who need them and when they } \\
\text { need them, regardless of age, gender, place of } \\
\text { residence, personal finances, or ethnic } \\
\text { background, and to facilitate research and } \\
\text { training }\end{array}$ \\
\hline
\end{tabular}

\subsection{A General Description of the Different SOE Arrangements' Purpose and Content}

Table 3 lists some characteristics of the different cases' governance arrangements.

Table 3. Overview of the case SOEs' arrangements.

\begin{tabular}{|c|c|c|c|c|}
\hline Case & $\begin{array}{l}\text { SOE Established } \\
\text { (Year) }\end{array}$ & $\begin{array}{l}\text { Project Governance } \\
\text { Arrangement } \\
\text { Established (Year) }\end{array}$ & $\begin{array}{l}\text { Projects with } \\
\text { Completed Qas } \\
\text { (Number) }\end{array}$ & $\begin{array}{l}\text { Threshold Value (for } \\
\text { Governance } \\
\text { Arrangements to Apply) }\end{array}$ \\
\hline State Project Model & - & 2000 & $\begin{array}{l}\text { QA1: 100 } \\
\text { QA2: } 200\end{array}$ & $\begin{array}{l}\text { USD } 110 \text { million } \\
\text { (ICT projects } \\
\text { USD } 35 \text { million) }\end{array}$ \\
\hline Avinor & 2003 & 2013 & $\begin{array}{l}\text { QA1: } 4 \\
\text { QA2: } 10\end{array}$ & USD 35 million \\
\hline Bane NOR & 2016 & 2017 & 5 & USD 90 million \\
\hline Nye Veier & 2015 & 2016 & 9 & $\mathrm{~N} / \mathrm{A}$ \\
\hline Statnett & 1991 & 2013 & 3 & $\begin{array}{c}300 \mathrm{kV} \text { voltage level, and } \\
\text { minimum } 20 \mathrm{~km} \text { grid } \\
\text { length }\end{array}$ \\
\hline $\begin{array}{l}\text { Regional health } \\
\text { authorities }\end{array}$ & 2001-2007 & 2002, 2011, 2015 & $\begin{array}{c}\text { ca. } 20 \\
(16 \text { after } 2015)\end{array}$ & USD 60 million \\
\hline
\end{tabular}


The positive experiences with the SPM have been an argument for other public organizations outside the SPM to introduce similar arrangements, which they do voluntarily. The majority of the studied SOEs' governance arrangements share the same purpose of providing a sufficient decision basis for conceptual and investment decisions. The exception is Statnett, where the purpose is to anchor the need for measures and solutions sufficiently, both in a political and societal manner. As can be seen from the year of establishment of the arrangements and the number of projects with completed QAs shown in Table 3, the majority of arrangements are new and have not gained the same amount of experience as the SPM.

As opposed to the SPM, the target group for the QA for the majority of the studied SOEs is the SOEs themselves, with one exception (Statnett). Still, the line ministries require the SOEs to have governance arrangements to ensure realistic budgets and cost control. The exception is Avinor, which initiated its arrangement on its own initiative. The SOEs arrangements generally appear less comprehensive than the SPM, and the differences are discussed in the following subsections.

\subsubsection{Stage-Gate Models}

All five SOEs have governance frameworks based on a stage-gate model performing external QA at selected decision gates, as shown in Figure 4, together with the SPM.

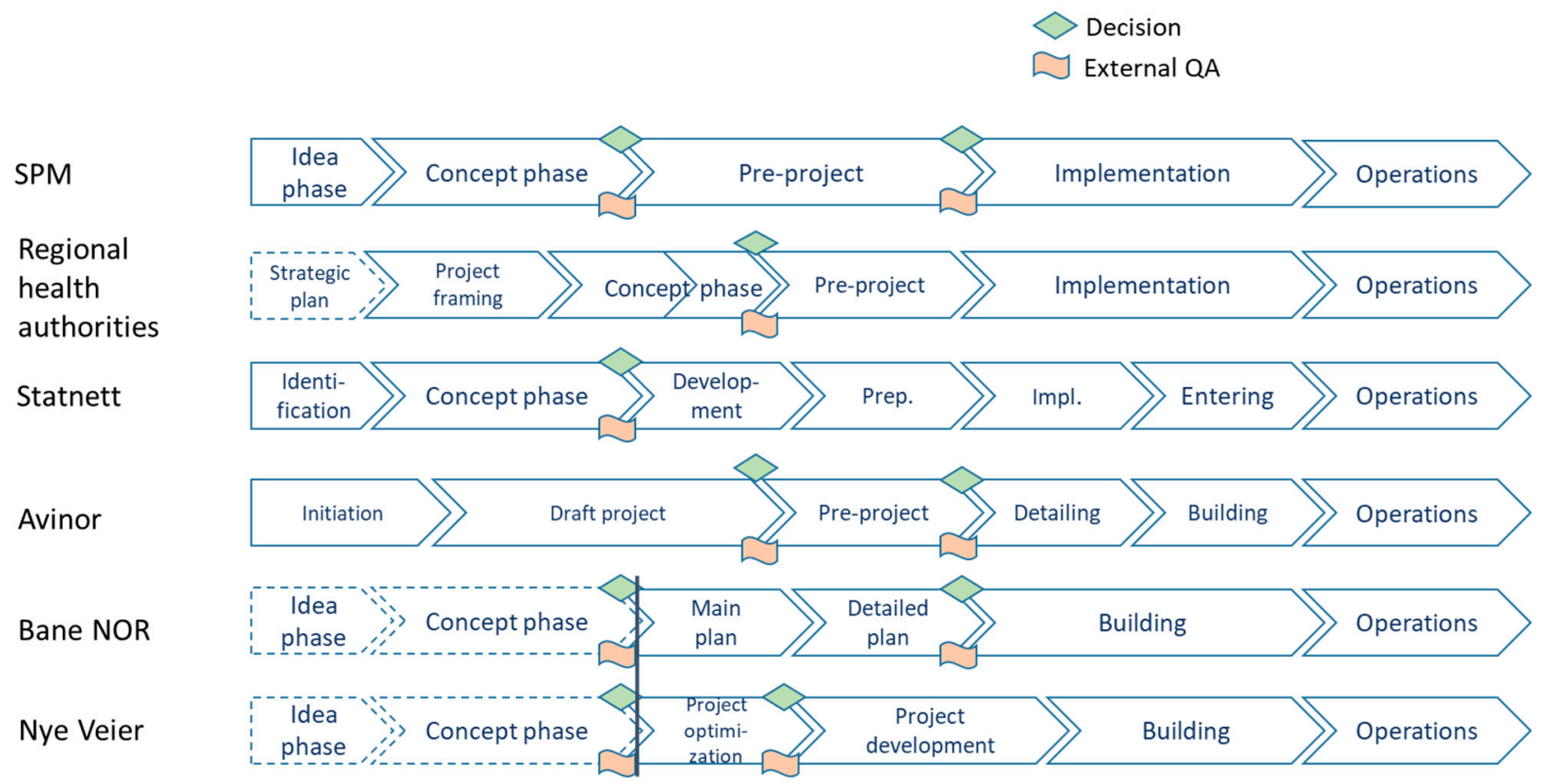

Figure 4. The stage-gate models for project governance for the case SOEs and the Norwegian State, showing the different project phases, when external QA is performed and different decision points.

Three SOEs (regional health authorities, Statnett and Avinor) perform external QA of the business case in the same way as the SPM (QA1), although somewhat later, while two SOEs (Bane Nor and Nye Veier) are only responsible for pursuing projects selected by the Government after an ordinary SPM QA1 process (vertical line in Figure 4).

\subsubsection{Contents of the Quality Assurance (QA)}

Table 4 shows the different arrangements' topics subject to QA. 
Table 4. Different arrangements' topics subject to QA.

\begin{tabular}{|c|c|c|}
\hline Case & "Doing the Right Project" & "Doing the Project Right" \\
\hline State Project Model & $\begin{array}{l}\text { Needs objectives, feasibility analyses, } \\
\text { financial terms } \\
\text { QA of choice of concept before Cabinet } \\
\text { decision to start the pre-project }\end{array}$ & $\begin{array}{l}\text { Management base, contractual strategy, cost } \\
\text { estimations, uncertainties, change records, } \\
\text { benefits/conceptual choice } \\
\text { QA of the management base and cost estimates } \\
\text { before the project is submitted to Parliament } \\
\text { for approval and funding }\end{array}$ \\
\hline Avinor & $\begin{array}{l}\text { Needs analysis, strategy, demands, } \\
\text { feasibility studies, recommendations for } \\
\text { pre-project }\end{array}$ & $\begin{array}{l}\text { Management base, contractual strategy, cost } \\
\text { limits, uncertainties, success factors }\end{array}$ \\
\hline Bane NOR & Performs QA1 as the State Project Model & $\begin{array}{l}\text { Management base, objectives, contractual } \\
\text { strategy, uncertainties, simplifications, } \\
\text { organization/governance, cost limits }\end{array}$ \\
\hline Nye Veier & Performs QA1 as the State Project Model & $\begin{array}{l}\text { Costs and uncertainties, socioeconomic } \\
\text { analysis and basis for traffic, organization, } \\
\text { governance, contractual strategy, funding }\end{array}$ \\
\hline Statnett & $\begin{array}{l}\text { Needs analysis, objectives, project } \\
\text { framing, feasibility studies, } \\
\text { recommendations for pre-project }\end{array}$ & No QA2 \\
\hline Regional Health Authorities & \multicolumn{2}{|c|}{$\begin{array}{l}\text { Agreement according to strategical plan, objectives hierarchy, feasibility studies as a } \\
\text { function of the health authorities' financial capacity/sustainability, localization, patient } \\
\text { safety }\end{array}$} \\
\hline
\end{tabular}

The SOEs' QA process is parallel, unlike the SPM. For the enterprises performing QA of the business case, the topics covered are similar to those found in the SPM, but the scope and terminology differ, as discussed in the following subsections. QA of the management base and cost estimates (i.e., QA2 in the SPM, where the purpose is to ensure budget realism and to ensure a more efficient use of resources) share even more similarities with the SPM.

\subsubsection{Researchers' Assessments}

All SOEs have governance arrangements based on the SPM regime regarding which phases should be subject to QA and which topics should be covered, with the exception of the regional health authorities.

However, some differences were found especially connected to "doing the right project". To ensure strategical project success, it is essential to find a relevant and sustainable solution to the given problem that the project is set to solve, by exploring the opportunity space in order to find a concept that serves the purpose (Samset et al. 2014).

The SOEs interpret the concept term more narrowly compared with the SPM. SOEs often look at variations of the same concept and not at unique conceptual solutions. For example, for hospital projects, all assessed concepts tend to involve new buildings, comprising variations of alternative dimensions or localization, or both. The SOEs rather focus on whether their preferred solution is well documented, and thus the conceptual choice, as defined in the SPM, is made in advance.

The narrow interpretation of the concept may be due to limited mandates of the SOEs. However, it is unfortunate that terminology related to major projects is inconsistent, and it should be clarified. Thus, discussions on what constitutes a concept would be valuable, especially for hospital projects, as also stated by Larsen et al. (2020). Broader analyses and a wider exploration of the opportunity space in order to find unique solutions might be suggested, although it is known from experience with the SPM that interpreting the meaning of the concept term is demanding and has been discussed for years. However, this could serve as a beneficial starting point for improvement, although, balancing concept 
elaboration and political decision making is a well-known challenge, and is yet to be solved (Klakegg et al. 2016).

Potential variations in the content of QA due to scope flexibility might challenge the governance arrangements' legitimacy and accountability when the analytical basis is affected by increasing unpredictability and reduced transparency. Furthermore, flexibility is considered crucial (Müller et al. 2014; Volden and Andersen 2018), thus indicating that finding a proper balance between demands and possible adaptions is important.

Moreover, a wider use of the business case along the project life cycle in the SOEs than for projects under the SPM was discovered. This situation has recently changed in the SPM, and the business case, (i.e., the project benefits) will also be emphasized in this arrangement after the concept phase. Thus, use of the business case has served as a learning point between the different arrangements.

\subsection{Actors, Roles and Political Aspect}

The different actors and roles vary between the SPM and the SOEs' arrangements, as illustrated in Figure 5 (the left pane shows the SPM; the right pane shows a simplified version of the SOEs, as there are variations between the different SOEs).

SPM

(incl. road/rail

considering conceptual choice)

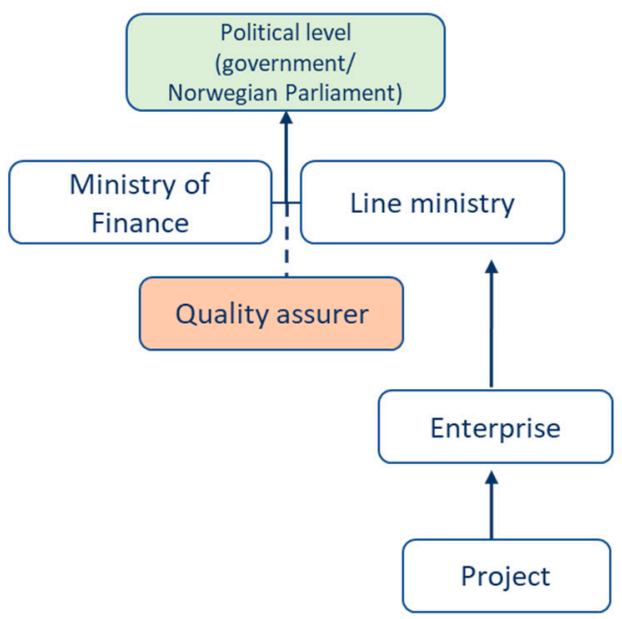

SOE

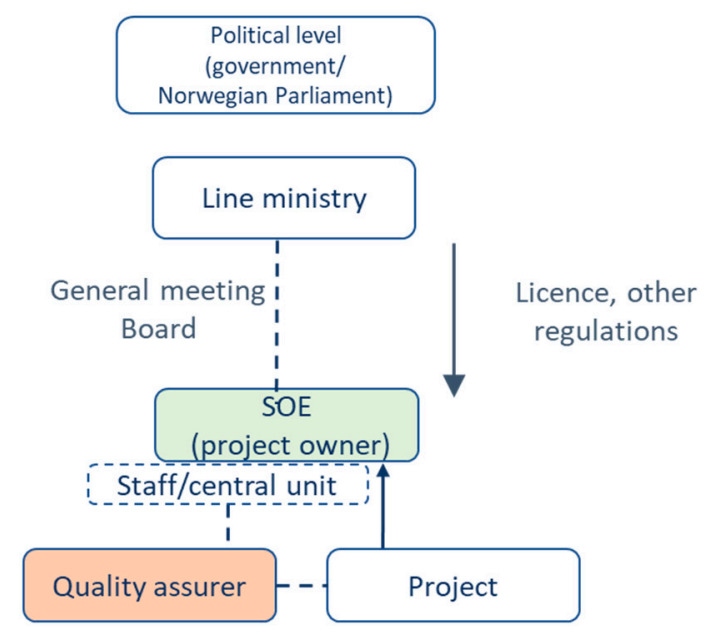

Decision $\square$ External QA

Figure 5. Organization of actors in the SPM and SOE arrangements.

The line ministries own the projects for the respective SOEs, as opposed to projects under the SPM, where project ownership should be considered as part of a hierarchy comprising the government, the line ministry and the agency (as discussed in Volden and Andersen (2018)). In the SPM, the process towards starting the projects is initiated by the line ministry, generally in consultation with the subordinate agency. The MoF contracts the external quality assurers who, after completion of their assessments, provide a general recommendation to the MoF and the respective line ministry. Decisions on project concept and funding are further made at the political level, namely by the government and parliament. The funding is made to the actual agency through the line ministry.

The SOEs' initiate their own projects and necessary elaborations, and contract the external quality assurers. For the SOE projects, the quality assurers provide their recommendations to the SOE, which mainly serves as the decision maker for the project's continuance. The line ministries may be involved in the processes either as shareholder or as licensing authority, lender or governor. However, in these projects, state ownership does not imply governing/controlling the individual projects. Investment decisions are generally not 
decided at the political level by the government or parliament. Line ministries' corporate governance is mainly practiced through the appointment of a board. However, the QA might be of relevance for the authorities when they are acting as a licensing authority, lender or governor, particularly in the case of major projects' licensing concerning the national electricity grid or transmission grid (Statnett). In these projects, the purpose of the external QA is to demonstrate the project's benefit-cost efficiency. By contrast, Avinor is dependent on licenses for new development projects, but there is no similar relation to external QA, and according to the respondents, the Ministry for Transport only to a minor extent practices political control when acting as a licensing authority. In the case of Bane Nor, Nye Veier and the regional health authorities, reports from their respective QAs serve as the decision basis for funding and development of railroads, roads and hospitals, respectively, but the respondents indicated that there no political judgements were involved in these projects. The external QA rather becomes a way of making the different SOEs financially accountable for the projects.

\subsubsection{Political Distancing}

The SOEs' arrangements contribute to a political distancing compared with the SPM. The line ministries' degree of involvement differs, thus affecting how political control is exerted. The political distance may make it easier for the projects to perform rational assessments regarding investment needs, life cycle costs, and profits in a long-term perspective. However, several respondents also held that the political distance made it more difficult for the projects to include sufficient political and societal considerations. The SOEs ${ }^{\prime}$ arrangements are primarily tools for supporting the boards and management in making the right decisions, and are not made for the purpose of serving the State's and wider society's interests. As formulated by one of the quality assurers:

"Our job in these arrangements is to provide safety for the board and management to make the right decisions, not to be the State or society's agents"

This contrasts the general purpose of governance arrangements as a way to provide central political power to the decisions on major public projects and to further anchor the projects at the central level (Christensen 2011).

Deviating from the general purpose might compromise legitimacy and accountability by undermining central control and further compromise strategical project success by losing sight of the bigger societal picture. As an example, one of the State's objectives with Avinor is to manage Norway's network of airports. Avinor is required to operate in profit, and thus the enterprise should focus on clients and business that provide revenue for the company, namely passengers, goods transport and duty-free sales. Society at large is increasingly concerned with environmental and sustainability issues, but the focus in Avinor is on developing air services that will lead to an increase in passenger and freight traffic. There are, surprisingly to some, no political assessments connected to these questions or to suitable arenas for holistic discussions in parliament, government and the line ministries. Several respondents highlighted the political distance in these processes, where discussions regarding environmental policies and alcohol policies should be carried out on a national level. The exception is larger projects that need additional governmental grants and are mentioned in the National Transport Plan. These projects will be subject to the SPM.

Except for the regional health authorities, there is no tradition of political governing of single projects in Norway. As several of the respondents said:

"Since the governmental level does not have a clearly defined role in these governance regimes, governmental interventions may lead to decisions that are even more "political" or random".

However, for the development of health services, for which considerable changes to existing services have been suggested, such as the closing down of hospitals, decisions should be made by the Ministry of Health and Care Services, following health legislation. 
Due to political complexities associated with these situations, it is regarded as a challenge for the health authorities to let go of their governing rights, thus illustrating how uncertainty and the level of conflict may influence the delegation of authority (Huber and Shipan 2013).

To summarize, this study shows that in the case of airports, the SOE (Avinor) seems to escape politics altogether. In the case of hospitals, it seems to be "pretended" that there is an arm's length to politics, but the government has found other (less predictable?) ways to exercise power, while in the case of the electricity grid, highways and railroads, political control over the choice of concept is ensured (at least in principle) in the same way as for ordinary public projects. This contrasts with the criticism of the SPM regarding too much political involvement, where seemingly some of the SOEs have gone too far in the opposite direction.

Conferring to critique against NPM from a political science and organizational theory point of view (e.g., Christensen 2011) and possible unfortunate outcomes resulting from decentralization of decision making (Simon 1944), the government should ensure that political control is not undermined. This is especially important for SOEs with sectoral policy objectives, in order to keep the societal perspective and thus strengthen the possibilities for strategically successful projects-that is, doing the right project (e.g., Williams and Samset 2010). As mentioned earlier (cf. "Political distancing"), there exist cases of investment decisions taken by an SOE that clearly affect the broader policy pursued by society and the use of its resources with very little political involvement.

\subsubsection{Administering the QA Scheme}

As opposed to the SPM, the SOEs themselves are responsible for both producing the decision basis and for contracting its external QA. Responsibility for handling elaborations in an early phase varies among the SOEs, as does the establishment of a dedicated project organization. There are variations regarding how responsibility for contracting external QA is designated: in some cases, the project itself is responsible, but for most cases the responsibility lies with a more centralized unit at the SOE level. For example, Nye Veier has moved the responsibility for contracting from the project manager to project management office level. For hospital projects, the relevant regional health authority serves as project owner, while the Norwegian Hospital Construction Agency is responsible for contracting the QA. This might become a challenge, since the agency is used as project managers or advisors in hospital projects exceeding USD 60 million, and thus risks contracting QA of its own work.

It could be argued that line ministries or other authorities should be involved in administering the QA in cases where they are target groups for the QA report. However, some respondents held that this would compromise the SOEs' independence.

The Railway Directorate and the Norwegian Water Resources and Energy Directorate use the QA reports for assessments regarding investments and development of railroads and the electricity grid, respectively, but do not have a role in contracting the QA.

Some variations are also seen regarding how the contracting is carried out. With the exception of Statnett, all SOEs have long-term framework agreements with between three and six companies or constellations of companies. Most SOEs contract the companies through competitive bidding, as opposed to the SPM, whereby quality assurers are contracted by aiming to attain a certain percentage distribution of the assignments seen over time.

All SOEs are concerned with using limited time and resources on the QA process, thereby limiting the scope of the QA assignments, aiming to gain early access to the quality assurers' recommendations. The importance of keeping the assessed projects up to speed is emphasized, since project delays are regarded as a considerable disadvantage for financial and other reasons. For example, hospital projects have a high degree of user involvement, making it important for them to keep to the project timeline. One of the quality assurers, however, pointed out that: 
"If the SOEs aim at using limited time on quality assurance, it is important that the elaborations and reports presented by the SOEs are of good quality initially"

\subsubsection{The Quality Assurers' Role}

Both commissioning practice and performance of the QA process make the distance between the quality assurer and the SOE/project less than in the SPM, as illustrated in Figure 5. In the SPM, quality assessments happen at specific points and by truly external consultants without much dialogue between the parties, while the SOEs mainly perform parallel assessments. The closeness between the SOEs' projects and the external quality assurers may make the exchange of professional advice easier, but at the same time challenge the impartiality, especially since the QA process is parallel. The parallel process may affect the quality assurers' role, making it more advisory, and the quality assurers risk assessing their own advice since they receive continuous versions of the decision documents. For some SOEs, this is deliberate and explained by the arrangements immaturity and the wish for consecutive assessments of practice. In some cases, the process also seems necessary, due to high degrees of insufficiency in the assessed reports; hence, the quality assurers need to tell the projects what to do. This practice was in many ways considered valuable and meaningful by the respondents from the SOEs, and the closeness created between the quality assurers and the projects makes it more likely for the quality assurers' advice and recommendations to be accepted. As a respondent from one of the SOEs said:

"Looking strictly at the $Q A$, the quality may become better if the quality assurers were allowed to sit for themselves in peace and quiet, working on the quality assurance report for half a year, but it is not worth it"

Working together and drawing on the different actors' experience and competence potentially creates a sound culture for decision making as part of project governance, which in turn might be beneficial for the project performance (Turner 2020b). Knowledge sharing may improve the internal quality of work and it can also facilitate the learning and knowledge exchange process between different entities (Hussein 2020; Nesheim and Hunskaar 2015).

The expected contents of the QAs appear as more flexible in the SOEs' arrangements, and the specifications regarding what to include are experienced as more guiding than absolute, as opposed to the SPM's specifications. This makes it possible for the SOEs to assess the scope of the QA for each project, which then becomes subject to competitive bidding. In the SPM, the specifications are set in framework agreements, and have recently been defined in a directive. Some of the respondents described the flexibility as a positive feature of the SOEs' arrangements, while others expressed their concern about possible large variations in the QAs' contents and quality resulting from the flexibility.

\subsubsection{Researchers' Assessments}

Three main observations are made concerning actors and roles in the SOEs, which differ from the SPM:

- Decisions on SOEs' projects are made by the projects themselves and not at the political level by the government or parliament;

- Administration of the QA arrangements is carried out closer to the project, making QA less independent;

- The quality assurers are forced to be more flexible, mainly due to the projects' desire to avoid pauses.

Transferring responsibilities for decisions regarding societal needs from the political level to SOEs with limited sectoral objectives should be carried out consciously. It may be questioned that SOEs are responsible for their own QA arrangements and the further use of the QA reports for decision making by the authorities. For the SOEs, the reports are mainly aimed at the different enterprises and might not cover the authorities' need for information. 
Therefore, the authorities should thoroughly consider whether the reports' contents are sufficient for their needs, and whether a sufficient societal perspective is present.

Choosing the right concept is vital for strategical project success, hence SOEs' elaboration of concepts should take a holistic societal perspective by sufficiently exploring the opportunity space (Klakegg and Haavaldsen 2011; Samset and Christensen 2017). The choice of concept, especially in the case of hospitals and airports, should take a more holistic societal perspective and the Government should be given a formal role in approving the projects. This corresponds to the general critique against NPM regarding the decentralization of power in matters important to the society (e.g., Christensen 2009, 2011). However, for Bane NOR and Nye Veier, conceptual decisions are made at the central level, delegating authority to the SOE afterwards. This might be beneficial considering the level of uncertainty and potentially high levels of conflict that can occur in the earliest project phases (Huber and Shipan 2013). Premature concept decisions compromise exploration of the opportunity space, and may lead to early lock-in (Flyvbjerg 2014). Therefore, the SOEs have much to learn from the SPM, in which wide assessment criteria are used, aiming for a comprehensive assessment of the project's societal usefulness. For SOEs, the assessments of projects are generally rather narrow, in which commercial considerations or achievements of limited sectoral objectives seem more pronounced than making broad societal assessments. On the basis of this study, it is suggested to perform broader benefit-cost analyses for the largest SOE projects.

Even if the closeness between the SOE and the quality assurers due to the parallel QA process is seen as beneficial, there is a risk of compromising the impartiality that should be prominent in such processes. It could be argued that the quality assurers should be given a formal opportunity to state when the decision basis is insufficient, similar to formal arrangements within the SPM.

\subsection{Scope and Use of Resources in Quality Assurance}

The respondents from the SOEs held that their arrangements were more efficient than the SPM, the scope was generally less ambitious, and the QA process was often parallel and generally more flexible. This, in turn, led to more efficient implementation of the investment projects. The MoF has made an effort to make the SPM more efficient and has managed to shorten the time spent on the assessments over the years. The average cost has been reduced for QA2, while for QA1 the average cost has increased, most likely due to a few projects' need for extensive elaborations. QA costs and time used per QA review are illustrated in Table 5.

Table 5. QA costs and time used in the studied different arrangements.

\begin{tabular}{ccc}
\hline Case & Average Cost per QA Review & Time Used per QA Review \\
\hline \multirow{4}{*}{ State Project Model } & September 2015-September & September 2015-September \\
& 2019: & 2019: \\
& QA1: USD 330,000 & QA1: 8 months \\
QA2: USD 202,000 & QA2: 5 months \\
Bane NOR & QA1: USD 57,500 & 2-3 months \\
Nye Veier & QA2: USD 57,500 & 8 weeks (sometimes more) \\
QA2: USD 57,500 & 6 weeks (sometimes more) \\
Statnett & 3-4 months in total (split \\
& Between USD 115,000-172,000 & $\begin{array}{c}\text { process; quality assurers may } \\
\text { use 6 weeks on each part) } \\
\text { 2 weeks when using parallel } \\
\text { arrangements, 6 weeks when } \\
\text { using point evaluation }\end{array}$ \\
\hline
\end{tabular}

Several of the respondents from the MoF and quality assurers affiliated with the SPM held that there was potential for improving the SPM's efficiency. However, it remains 
unclear as to what extent it can be improved and what the actual degree of improvement has been in recent years. Some minimum requirements limit the ability to shorten time and/or reduce costs. This depends on the quality of the final reports and complexity of the project. The MoF holds that efforts to improve the QA2 are limited, while there is potential for improvement of the QA1. However, as several quality assurers claimed:

"The choice of concept is the most important decision, and attempts to shorten the process by a few weeks in order to save time and money clearly is the wrong focus"

The respondents put forward some suggestions for how to improve the arrangements' time and cost efficiency, such as providing target figures or demands for time and cost, thus signaling the importance of these issues for the State. This would further force quality assurers to take on a risk-based approach by focusing on the weakest links in the decision basis and not treating every issue equally thorough. Further, the respondents stressed the importance of a qualitatively sufficient and complete decision basis to shorten the time spent on QA. They also mentioned the possibility for performing a "light" version of the QA, whereby the quality assurers could assess the available documentation and not perform their own independent analyses, given that project owners are experienced and projects are less complex. Looking at this from another perspective, one of the quality assurers said that:

"Pretending that everything is equally important may constitute a risk for covering the important issues among the less important ones"

When assessments are finished, it is common for quality assurers to write an extensive report, involving a considerable number of working hours. Some respondents pointed to the possibility of simplifying the report, more in line with the standards of some of the other QA arrangements. Furthermore, the respondents point to the number of actors attending the QA constellations as a factor that might drive up the costs, due to the need for coordination and involvement. The State's constellations are quite large, comprising typically three or four companies.

\subsubsection{Are Some Arrangements Too Scarce?}

Considering costs and time spent, the thoroughness of the SPM makes it a candidate for improvement. Using this as a backdrop, one could ask whether the SOEs' arrangements are too scarce or too narrow. The SOEs find their arrangements sufficiently thorough, and point to the external QA as part of an extensive QA system, which also includes internal assessments. Most enterprises/agencies have their own arrangements, but it could be argued that enterprises that have their own boards and that are financially responsible for a project portfolio may have stronger incentives for such arrangements. However, it should be emphasized that the case SOEs are still state-owned companies managing the State's assets, and thus the societal perspective should be given prominence by securing political control through a suitable level of state governance. Irrespective of the State's more or less direct involvement in the external assessments, it is important to ensure the necessary premises for the quality assurers to do a good job. One of the respondents exemplified this by saying:

"... a superficial $Q A$ report could become an alibi that would lead the decision-makers to make their decisions on false premises"

The quality assurers mentioned difficulties in providing good advice or recommendations when there was limited room for making their own analyses, which is common practice for project assessment under the SPM. The majority of arrangements do open for control calculations and provide grounds for extended analyses when needed. However, in practice it may be difficult to manage this within the scope of the current arrangements.

Some respondents held that QA is more important when projects are immature, and that given that the SOEs' arrangements are young and still under development, the QA should be seen as a valuable asset. The quality assurers shared the opinion that some of 
the SOEs lacked project maturity compared with the agencies under the SPM, which may emphasize the need for QA of projects in these enterprises.

Another factor influencing the QA is the SOE projects' need for progress in order to be included in the state budget for the current year. This affects time spent on the QA and serves as the main reason for choosing the parallel approach to QA. However, as pointed out by several of the quality assurers, the need for progression may compromise the quality of the assessments, making it too narrow and making it hard to judge whether the decision basis is insufficient and whether to recommend further assessments.

\subsubsection{Researchers' Assessments}

Our findings show that the SPM is more extensive than the case SOEs' arrangements. The SOEs largely manage to control the time and resources spent on the QA process because they administer the arrangements themselves. The pronounced need to keep to the project cost and timeline makes parallel QA practice widespread among the SOEs.

Finding the appropriate level of external QA is challenging, as seen from the studied arrangements. The project model, corporate governance and other incentives will affect the scope and use of resources in the external QA, leading to variations among arrangements and chosen actions. However, when searching for an optimal balance there should be potential learning points between the SPM and the SOEs' arrangements. Depending on the projects' complexity and scope, the SPM could benefit from becoming more flexible, thus improving its efficiency and making it simpler. Attempting to achieve an optimal balance, experiences and knowledge should be shared among the different arrangements. This enables development of ideas and could help in implementing practices and procedures (Wang and Noe 2010). To facilitate such knowledge sharing processes, the establishment of suitable arenas for this purpose would be beneficial (Söderlund 2002), which also corresponds to one of several identified factors shown to influence knowledge sharing behavior (Wang and Noe 2010).

However, it is unclear whether the potential for improvement is due to the QA arrangement itself or how it is practiced. Moreover, is it unclear to what extent the SPM may be improved. The quality of the assessments should not be compromised by improving efficiency. Still, the quality assurers' influence on the arrangements could be questioned and whether they possess the right incentives to suggest a simplified QA process whenever possible.

For the less comprehensive SOE arrangements, the quality assurers should be allowed sufficient time and perhaps a more prominent role to facilitate their work. The considerable focus on maintaining scheduled time and costs should not compromise the quality of the QA. While this is not an explicit issue for all SOE arrangements, it is generally an important point to avoid superficial QA processes leading to unfortunate decisions. The quality assurers should be able to perform their own analyses when needed, namely when the decision basis is insufficient due to, for example, inadequate analysis or lack of transparency.

Additionally, the overall decision basis should be assessed as a whole, by asking whether it is sufficient for making decisions. To avoid a situation where the quality assurers assess their own recommendations, the original document should remain unchanged, and a change record should be made in addition. Limited data make it difficult for any conclusions to be drawn as to which arrangements are sufficient and which are not, based on the differences found between the SOE arrangements regarding the impact of time and cost pressure. However, it should still be recommended that the different SOEs evaluate whether the perceived time and cost pressure has unfortunate effects on the QA processes, as superficial QAs may not serve their purpose.

\section{Concluding Remarks}

This study set out to explore the governance arrangements of major public projects in SOEs in Norway, and in particular, how the recommended external QA part of these 
arrangements is organized and performed. The SOE arrangements are compared with the more established SPM governing the State's ordinary public projects, in order to establish a point of departure for mutual learning and improvement between the different arrangements.

From our comparison of the SOEs' QA arrangements with the SPM, it may be concluded that the SOEs' arrangements are more efficient, considering scope and use of time and resources. The SPM has been criticized for its comprehensiveness, and actions have been taken to improve it. Some learning points may be taken from the SOEs' arrangements in this manner.

Organizing state ownership in its own enterprises might be considered beneficial in several respects. However, the State should be aware of which decisions are "outsourced" due to such organizing and should ensure that a broad societal perspective is kept when decisions are made. Due to the SOEs' sectorial perspectives/objectives, this might become a challenge. Making the SOEs responsible for their own QA arrangements further contributes to distancing of decisions on potentially important societal matters from the political and democratic level. Centralizing responsibility for the QA might compensate for the decentralization of responsibility as described in the SOEs' arrangements. Furthermore, such centralization may strengthen the societal aspects that should be prominent in decision making concerning public projects, in order to achieve strategical success.

Strategical success is also sought through decisions on the conceptual solution, when it is essential to keep a holistic societal perspective. The discussion on what constitutes a concept should be emphasized in the SOEs, and in this regard experiences of the SPM over the past two decades would be useful, aiming for a harmonization of the terminology and the use of broad assessment criteria.

Further, the quality assurers' role in the SOE arrangements and their closeness to the SOEs' projects should be emphasized, which may compromise the necessary impartiality that should be present in such processes. Even if the SOEs see the parallel QA arrangements and close relation as an advantage, it is considered reasonable to point this out as a potential risk factor.

Compared with the SPM, which has been a research topic for two decades, the SOEs' arrangements are relatively immature, and therefore the need for more research is pressing. Continuing research on the different arrangements' development, especially connected to relative effects on cost control, achievement of tactical and strategical objectives, and other success criteria would presumably be beneficial for further improvements and learning, also seen in an international context. This may guide us towards finding the right level of external QA, and how to balance this against internal QA arrangements. Gaining further knowledge of the schemes would also be beneficial for assessing which topics to emphasize in the QA reports, how to organize the arrangements, and how the quality assurers' role should be balanced in favor of acting as an advisor. Further knowledge on these topics might contribute to more predictability, which in turn would improve the decision-making environment, and which could, according to Turner (2020a, 2020b), lead to better project performance.

\section{Research Implications}

This study advances our general understanding of SOEs and the governance of major public projects undertaken in such enterprises, both of which are research topics in need of further knowledge. This study points to the SOEs' challenging role in balancing independence and efficiency with the need to keep a holistic, societal perspective and make societal decisions at the right political level. It provides an illustration of challenges following public reforms, such as NPM, underlining former criticism regarding delegation of decision making and thus political distancing of societal matters.

This study also adds to the general understanding of governance of major public projects' front-end phase by establishing more knowledge of such projects undertaken in a context distant from central politics. The SOEs still administer considerable public 
resources and interests, and should make serious efforts to "do the right project", to achieve strategical project success. Making the SOEs responsible for both QA of the projects and the subsequent decision-making process requires clearly stated mandates from the central political level, in order to enable a holistic societal perspective to be retained. Our comparison of the SOEs' governance models with the more established SPM that follows theoretical recommendations from project management literature, and that is used for governing public projects undertaken in a political context in which decisions are centralized in order to maintain societal interests, contributes to creating a point of departure for improvement and mutual learning among the different arrangements. Through this comparison, and as a practical contribution, this study has made it possible to offer some recommendations to the SOEs and their line ministries regarding topics that might compromise project performance if not dealt with properly:

- External QA should focus on concept elaboration and, in order to take on a holistic societal perspective, it should be performed early enough (in the projects' front-end phase).

- Care should be taken regarding which decisions are political in nature, and it should be ensured that decisions are anchored in the right (governmental) level.

- Sufficient resources for external QA should be provided.

- Capability/awareness of the need to balance external quality assurers' impartiality with the required and desired process efficiency is important when using parallel QA arrangements.

- Arenas should be established to promote mutual learning between the different arrangements through sharing knowledge and exchanging experiences and advice.

Author Contributions: Conceptualization, G.H.V. and B.A.; methodology, G.H.V. and B.A.; investigation, G.H.V., B.A., partly A.S.A.L.; formal analysis, G.H.V., B.A. and A.S.A.L.; writing-original draft preparation, A.S.A.L.; writing-review and editing, A.S.A.L., G.H.V., B.A. All authors have read and agreed to the published version of the manuscript.

Funding: This research is partly funded by the Research Council of Norway through the Public sector PhD-scheme, grant no. 272377.The work was supported by the Concept Research Programme at the Norwegian University of Science and Technology, which in turn is funded by the Norwegian Ministry of Finance.

Institutional Review Board Statement: Not applicable.

Informed Consent Statement: Informed consent was obtained from all subjects involved in the study.

Data Availability Statement: Not applicable.

Conflicts of Interest: The authors declare no conflict of interest.

\section{References}

Ahola, Tuomas, Inkeri Ruuska, Karlos Artto, and Jaakko Kujala. 2014. What is project governance and what are its origins? International Journal of Project Management 32: 1321-32. [CrossRef]

Ali, Imran, Ata Ul Musawir, and Murad Ali. 2018. Impact of knowledge sharing and absorptive capacity on project performance: The moderating role of social processes. Journal of Knowledge Management 22. [CrossRef]

Amayah, Angela Titi. 2013. Determinants of knowledge sharing in a public sector organization. Journal of Knowledge Management 17: 454-71. [CrossRef]

Bernier, Luc, and Eoin Reeves. 2018. The continuing importance of state-owned enterprise in the twenty-first century: Challenges for public policy: The continuing importance of state-owned enterprise in the twenty-first century. Annals of Public and Cooperative Economics 89: 453-58. [CrossRef]

Bevir, Mark. 2013. A Theory of Governance. Berkeley: University of Californi, Gaia Books.

Bowen, Glenn A. 2009. Document Analysis as a Qualitative Research Method. Qualitative Research Journal 9: 27-40. [CrossRef]

Brunet, Maude, and Monique Aubry. 2016. The three dimensions of a governance framework for major public projects. International Journal of Project Management 34: 1596-607. [CrossRef]

Campbell, John, Craig McDonald, and Tsholofelo Sethibe. 2010. Public and private sector IT governance: Identifying contextual differences. Australasian Journal of Information Systems 16. [CrossRef] 
Christensen, Tom, and Per Lægreid. 2003. Coping with Complex Leadership Roles: The Problematic Redefinition of Governmentowned Enterprises. Public Administration 81: 803-31. [CrossRef]

Christensen, Tom. 2009. The Norwegian Front-End Governance Regime of Major Public Projects-A Theoretically Based Analysis. Concept Report No. 23. Trondheim: Concept, NTNU.

Christensen, Tom. 2011. The Norwegian front-end governance regime of major public projects: A theoretically based analysis and evaluation. International Journal of Managing Projects in Business 4: 218-39. [CrossRef]

Ciolomic, Ioana-Andreea, and Ioana Natalia Beleiu. 2020. State-Owned Enterprises in the Context of Contemporary Transformations. Revista de Management Comparat International 21: 177-87.

Crawford, Lynn H, and Jane Helm. 2009. Government and governance: The value of project management in the public sector. Project Management Journal 40: 73-87. [CrossRef]

Daniel, Pierre A., and Carole Daniel. 2018. Complexity, uncertainty and mental models: From a paradigm of regulation to a paradigm of emergence in project management. International Journal of Project Management 36: 184-97. [CrossRef]

Flyvbjerg, Bent. 2014. What You Should Know About Megaprojects and Why: An Overview. Project Management Journal 45: 6-19. [CrossRef]

Flyvbjerg, Bent. 2017. Introduction: The Iron Law of Megaproject Management. In The Oxford Handbook of Megaproject Management. Edited by Bent Flyvbjerg. Oxford: Oxford University Press, pp. 1-18.

Frey, Bruno S. 2005. Public Governance and Private Governance: Exchanging Ideas. In Multidisciplinary Economics. Edited by Peter de Gijsel and Hans Schenk. Berlin/Heidelberg: Springer, pp. 167-86.

Grossi, Giuseppe, Ulf Papenfuß, and Marie-Soleil Tremblay. 2015. Corporate governance and accountability of state-owned enterprises: Relevance for science and society and interdisciplinary research perspectives. International Journal of Public Sector Management 28: 274-85. [CrossRef]

Huber, John D., and Charles R. Shipan. 2013. Politics, delegation, and bureaucracy. In The Oxford Handbook of Political Science. Edited by Robert E. Goodin. Oxford: Oxford University Press.

Hussein, Bassam. 2020. Let's Really Learn from Projects. A Study on Learning in Project Based Organizations. The Ivar Aasen Project, 1st ed.Bergen: Fagbokforlaget.

Haanæs, Sverre, Eilif Holte, and Stein Vegar Larsen. 2006. Beslutningsunderlag og beslutninger i store statlige investeringsprosjekt (Decision-Basis and Decisions in Major Public Investment Projects). Concept Report no. 3. Trondheim: Concept, NTNU.

Imam, Hassan, and Muhammad Kashif Zaheer. 2021. Shared leadership and project success: The roles of knowledge sharing, cohesion and trust in the team. International Journal of Project Management. [CrossRef]

Jugdev, Kam, and Ralf Müller. 2005. A Retrospective Look at our Evolving Understanding of Project Success. Project Management Journal 36: 19-31. [CrossRef]

Khan, Asadullah, Muhammad Waris, Ishak Ismail, Mirza Rizwan Sajid, Mehfooz Ullah, and Faisal Usman. 2019. Deficiencies in Project Governance: An Analysis of Infrastructure Development Program. Administrative Sciences 9: 9. [CrossRef]

Klakegg, Ole Jonny, Terry Williams, Ole Morten Magnussen, and Helene Glasspool. 2008. Governance Frameworks for Public Project Development and Estimation. Project Management Journal 39: S27-S42. [CrossRef]

Klakegg, Ole Jonny, and Tore Haavaldsen. 2011. Governance of major public investment projects: In pursuit of relevance and sustainability. International Journal of Managing Projects in Business 4: 157-67. [CrossRef]

Klakegg, Ole Jonny, Terry Williams, and Asmamaw Tadege Shiferaw. 2016. Taming the trolls: Major public projects in the making. International Journal of Project Management 34: 282-96. [CrossRef]

Klakegg, Ole Jonny, and Gro Holst Volden. 2017. Governance in public projects: The Norwegian case. In Governance and Governmentality for Projects: Enablers, Practices and Consequences. Edited by Ralf Müller. New York: Routledge, pp. 129-56.

Kvale, Steinar, and Svend Brinkmann. 2015. Det kvalitative forskningsintervju (Qualitative Research Interviewing), 3rd ed. Oslo: Gyldendal Akademisk.

Larsen, Anne Strand Alfredsen, Anniken Th Karlsen, and Bjørn Andersen. 2020. Hospital project front-end planning: Current practice and discovered challenges. Project Leadership and Society 1. [CrossRef]

Locatelli, Giorgio, Mauro Mancini, and Erika Romano. 2014. Systems Engineering to improve the governance in complex project environments. International Journal of Project Management 32: 1395-410. [CrossRef]

Marshall, Martin N. 1996. Sampling for qualitative research. Family Practice 13: 522-25. [CrossRef] [PubMed]

McLaughlin, Mark. 2019. Defining a State-Owned Enterprise in International Investment Agreements. ICSID Review-Foreign Investment Law Journal 34: 595-625. [CrossRef]

Miller, Roger, and Brian Hobbs. 2005. Governance Regimes for Large Complex Projects. Project Management Journal 36: 42-50. [CrossRef]

Ministry of Finance. 2019. Statens prosjektmodell- Krav til utredning, planlegging og kvalitetssikring av store investeringsprosjekter $i$ staten (The State Project Model- Demands for Elaborations, Planning and Quality Assurance of Major Public Investment Projects); Norway: Norwegian Ministry of Finance.

Morris, Peter W. G. 2009. Implementing Strategy Through Project Management: The Importance of Managing the Project Front-end. In Making Essential Choices with Scant Information: Front-end Decision Making in Major Projects. Edited by Terry M. Williams, Knut Samset and Kjell Sunnevåg. Houndmills: Palgrave Macmillan, pp. 39-64.

Morris, Peter W. G. 2013. Reconstructing Project Management. Hoboken: John Wiley \& Sons. 
Müller, Ralf. 2009. Project Governance: Fundamentals of Project Management. Aldershot: Gower.

Müller, Ralf. 2014. Project Governance. In Advances in Project Management: Narrated Journeys in Uncharted Territory. Edited by Darren Dalcher. Farnham: Ashgate Publishing, Ltd.

Müller, Ralf, Sofia Pemsel, and Jingting Shao. 2014. Organizational enablers for governance and governmentality of projects: A literature review. International Journal of Project Management 32: 1309-20. [CrossRef]

Narayanan, V. K., and Robert DeFillippi. 2012. The influence of strategic context on project management systems: A senior management perspective. In Project Governance: Getting Investments Right. Edited by Terry Williams and Knut Samset. Basingstoke: Palgrave Macmillan, pp. 3-45.

Nasir, Hartini. 2017. State-Owned Enterprises: A Comparison Between the UK, Japan, and Malaysia. International Journal of Economics, Commerce and Management 5: 114-30.

Nesheim, Torstein, and Håavard Mørch Hunskaar. 2015. When employees and external consultants work together on projects: Challenges of knowledge sharing. International Journal of Project Management 33: 1417-24. [CrossRef]

Norwegian Ministry of Trade Industry and Fisheries. 2019a. The State Ownership Report 2019. Norway: Norwegian Ministry of Trade Industry and Fisheries.

Norwegian Ministry of Trade Industry and Fisheries. 2019b. Meld. St. 8: State Owned Enterprises. Sustainable Added Value (Meld. St. 8: Statens direkte eierskap i selskaper. Bærekraftig verdiskapning). Norway: Norwegian Ministry of Trade Industry and Fisheries.

Nutt, Paul C. 2006. Comparing public and private sector decision-making practices. Journal of Public Administration Research and Theory 16: 289-318. [CrossRef]

OECD. 2014. The Size and Sectoral Distribution of SOEs in OECD and Partner Countries. Paris: OECD.

OECD. 2018. Ownership and Governance of State-Owned Enterprises. A Compendium of National Practices. Paris: OECD.

Ongaro, Edoardo, and Ewan Ferlie. 2019. Exploring Strategy-Making in 'Non-New Public Management' Public Services Settings: The Case of European Union Agencies. Administrative Sciences 9: 23. [CrossRef]

Overman, Sjors. 2016. Great expectations of public service delegation: A systematic review. Public Management Review 18: $1238-62$. [CrossRef]

Rentsch, Carole, and Matthias Finger. 2015. Yes, No, Maybe: The Ambiguous Relationships Between State-Owned Enterprises And The State. Annals of Public and Cooperative Economics 86: 617-40. [CrossRef]

Samset, Knut, Peder Berg, and Ole Jonny Klakegg. 2006. Front End Governance of Major Public Projects. In EURAM 2006. Oslo: EURAM 2006.

Samset, Knut. 2009. Projects, Their Quality at Entry and Challenges in the Front-End Phase. In Making Essential Choices with Scant Information. Front-End Decision Making in Major Projects. Edited by Terry M. Williams, Knut Samset and Kjell J. Sunnevåg. London: Palgrave Macmillan, pp. 18-35.

Samset, Knut. 2010. Early Project Appraisal. Making the Initial Choices. Hampshire: Palgrave Macmillan.

Samset, Knut, and Gro Holst Volden. 2013a. Investing for Impact. Lessons with the Norwegian State Project Model and the First Investment Projects that Have Been Subjected to External Quality Assurance. Concept Report No 36. Trondheim: Concept, NTNU.

Samset, Knut Fredrik, and Gro Holst Volden. 2013b. Statens Prosjektmodell. Bedre Kostnadsstyring. Erfaringer Med de Første Investeringstiltakene som har vært Gjennom Ekstern Kvalitetssikring (The State Project Model). Concept Report No. 35. Trondheim: Concept, NTNU.

Samset, Knut, and Gro Holst Volden. 2016. Front-end definition of projects: Ten paradoxes and some reflections regarding project management and project governance. International Journal of Project Management 34: 294-313. [CrossRef]

Samset, Knut, and Tom Christensen. 2017. Ex ante project evaluation and the complexity of early decision-making. Public Organization Review 17: 1-17. [CrossRef]

Samset, Knut, Bjørn Andersen, and Kjell Austeng. 2014. To what extent do projects explore the opportunity space? A study of conceptual solutions. International Journal of Managing Projects in Business 7: 473-92. [CrossRef]

Saunders, Mark, Philip Lewis, and Adrian Thornhill. 2019. Research Methods for Business Students, 8th ed. Harlow: Pearson Education Ltd.

Serugga, Joas, Mike Kagioglou, and Patricia Tzortzopoulos. 2020. Front End Projects Benefits Realisation from a Requirements Management Perspective-A Systematic Literature Review. Buildings 10: 83. [CrossRef]

Simon, Herbert A. 1944. Decision-making and administrative organization. Public Administration Review 4: 16-30. [CrossRef]

Statskonsult. 1998. I Godt Selskap? Statlig eierstyring i teori og praksis. (In Good Company? State Governance in Theory and Practice). Available online: https:/ / dfo.no/filer/r98-21-I-godt-selskap-statlig-eierstyring-i-teori-og-praksis.PDF (accessed on 5 January 2021).

Stock, Gregory N., Jacob Chia-An Tsai, James J. Jiang, and Gary Klein. 2021. Coping with uncertainty: Knowledge sharing in new product development projects. International Journal of Project Management 39: 59-70. [CrossRef]

Söderlund, Jonas. 2002. Managing complex development projects: Arenas, knowledge processes and time. REd Management 32: 419-30. [CrossRef]

Sørensen, Rune. 2010. Ustyrlige statsselskaper? (Ungovernable state enterprises?). Beta 24: 38-56. [CrossRef]

Sørensen, Rune J., and Dag Morten Dalen. 2001. Eierskap og Tilknytningsformer i Offentlig Sektor. En Diskusjon og Empiriske Resultater i Internasjonal Forskning. (Public Sector Ownership and Bindings. A Discussion and Empirical Results in International Research). Available online: http://home.bi.no/a0110709/Eierskap.pdf (accessed on 5 January 2021). 
Tjora, Aksel. 2012. Kvalitative forskningsmetoder i praksis (Qualitative Research Methods in Practice). Oslo: Gyldendal Akademisk.

Too, Eric, Tiendung Le, Patrick Weaver, and Lynda Bourne. 2017. The Core Functions of Project Governance. EPiC Series in Education Science 1: 119-28.

Turner, J. Rodney, Frank Anbari, and Christophe Bredillet. 2013. Perspectives on research in project management: The nine schools. Global Business Perspectives 1: 3-28. [CrossRef]

Turner, Rodney. 2020a. How Does Governance Influence Decision Making on Projects and in Project-Based Organizations? Project Management Journal 51: 670-84. [CrossRef]

Turner, Rodney. 2020b. Investigating how governmentality and governance influence decision making on projects. Project Leadership and Society 1. [CrossRef]

Vagliasindi, Maria. 2008. Governance Arrangements for State Owned Enterprises. Policy Research Working Paper. New York: Sustainable Development Network.

Volden, Gro Holst, and Knut Samset. 2017a. Quality assurance in megaproject management. The Norwegian way. In The Oxford Handbook on Megaproject Management. Edited by Bent Flyvbjerg. Oxford: Oxford University Press, pp. 406-28.

Volden, Gro Holst, and Knut Samset. 2017b. Governance of major public investment projects: Principles and practices in six countries. Project Management Journal 48: 90-108. [CrossRef]

Volden, Gro Holst, and Bjørn Andersen. 2018. The hierarchy of public project governance frameworks: An empirical study of principles and practices in Norwegian ministries and agencies. International Journal of Managing Projects in Business 11: 174-97. [CrossRef]

Volden, Gro Holst. 2019a. Public funding, perverse incentives, and counterproductive outcomes. International Journal of Managing Projects in Business 12: 466-86. [CrossRef]

Volden, Gro Holst. 2019b. Assessing public projects' value for money: An empirical study of the usefulness of cost-benefit analyses in decision-making. International Journal of Project Management 37: 549-64. [CrossRef]

Wang, Sheng, and Raymond A. Noe. 2010. Knowledge sharing: A review and directions for future research. Human Resource Management Review 20: 115-31. [CrossRef]

Williams, Terry, Ole Jonny Klakegg, Ole Morten Magnussen, and Helene Glasspool. 2010. An investigation of governance frameworks for public projects in Norway and the UK. International Journal of Project Management 28: 40-50. [CrossRef]

Williams, Terry, and Knut Samset. 2010. Issues in Front-End Decision Making on Projects. Project Management Journal 41: 38-49. [CrossRef]

Williams, Terry, Hang Vo, Knut Samset, and Andrew Edkins. 2019. The front-end of projects: A systematic literature review and structuring. Production Planning \& Control 30: 1137-69. [CrossRef]

Yin, Robert K. 2014. Case Study Research: Design and Methods, 5th ed. Los Angeles: SAGE Publications. 